\title{
Evaluation of Heavy Metals Loading of River Ijana in Ekpan - Warri, Nigeria
}

\section{${ }^{* 1}$ EMOYAN, O O; ${ }^{1}$ OGBAN, F E.; ${ }^{2}$ AKARAH, E}

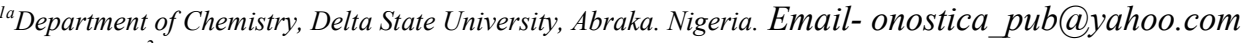 \\ ${ }^{2}$ Department of Physicals Health Education, Delta State University, Abraka, Nigeria.
}

\begin{abstract}
The concentration of Cadmium (Cd), Chromium (Cr), Copper (Cu), Iron (Fe), Nickel (Ni), Lead $(\mathrm{Pb})$ and $\mathrm{Zinc}(\mathrm{Zn})$ which may affect human health and the "health" of the aquatic ecosystem were determine in the River Ijana Ekpan, using a pye unicam Atomic Absorption Spectrometry SP model 2900. The level of heavy metal in the study area varied between $\mathrm{Cd}\left(0.010 \pm 0.004 \mathrm{mgl}^{-1}\right)$ and $\left(0.100 \pm 0.014 \mathrm{mg} 1^{-1}\right) ; \mathrm{Cr}\left(0.037 \pm 0.006 \mathrm{mg}^{-1}\right)$ and $\left(0.067 \pm 0.020 \mathrm{mg}^{-1}\right), \mathrm{Cu}\left(0.020 \pm 0.004 \mathrm{mg}^{-1}\right)$ and $\left(0.050 \pm 0.029 \mathrm{mg}^{-1}\right) ; \mathrm{Fe}\left(0.046 \pm 0.007 \mathrm{mg}^{1^{-1}}\right)$ and $(0.229 \pm$ $\left.0.008 \mathrm{mg}^{-1}\right) ; \mathrm{Ni}\left(0.030 \pm 0.004 \mathrm{mg}^{-1}\right)$ and $\left(0.080 \pm 0.010 \mathrm{mg}^{1-1}\right) ; \mathrm{Pb}\left(0.025 \pm 0.006 \mathrm{mg} 1^{-1}\right)$ and $\left(0.058 \pm 0.008 \mathrm{mg} 1^{-}\right.$ $\left.{ }^{1}\right)$ and $\mathrm{Zn}\left(0.088 \pm 0.012 \mathrm{mg}^{-1}\right)$ and $\left(0.122 \pm 0.007 \mathrm{mg}^{-1}\right)$. The concentration of these parameters of pollution contained in the study area $\left(\mathrm{SS}_{1}-\mathrm{SS}_{3}\right)$ indicated that the River is fairly polluted. The possible sources of these parameters of pollution are diverse: originating from anthropogenic / natural and point sources. @JASEM
\end{abstract}

Due to hydrodynamics, inland aquatic ecosystems are interconnected from the atmosphere to the sea, and as a result of their physical, chemical and biological characteristics they exhibit a high natural variability. They are therefore more susceptible to anthropogenic influence than the more consistent and stable marine ecosystems (Rainbow and Dallinger, 1993). The ability of a water body to support aquatic life as well as its suitability for other uses, depends on many trace elements. Some metals such as Manganese, Zinc, Copper, Iron, Nickel, when present in trace concentrations are important for the physiological functions of living tissue and regulate many biochemical processes (Rainbow and White, 1989; Sanders, 1997). Generally, trace amounts of metals are always present in freshwaters from the weathering of rocks and soils. In addition, industrial wastewater discharges and mining are major sources of metals in freshwaters. Through precipitation and atmospheric deposition, significant amounts also enter the hydrological circle through surface waters (Merian 1991; Robinson, 1996).

Some metals when discharged into natural waters at increased concentration in sewage, industrial effluent or from mining and refining operations, can have severe toxicological effects on aquatic environment and humans. (Merian, 1991; DWAF, 1996). In addition, heavy metals become toxic when a level is reached when it damages the life functions of an organism (Albergoni and Piccinni 1983). The toxicity of metals in solution depends on the degree of oxidation of a given metal ion together with the forms in which it occurs. For example, the maximum allowable concentration of $\mathrm{Cr}$ (IV) in the former USSR was $0.001 \mathrm{mgl}^{-1}$ whereas for Cr (III) it was $0.5 \mathrm{mgl}^{-1}$, as a rule however, the ionic form of a metal is the most toxic form (Bestemyanov and Krotov, 1985), the toxicity is reduced if the ions are bound into complexes e.g with natural organic matter such as fulvic and humic acids. Under certain conditions, metallo - organic, low molecular weight compounds formed in natural waters exhibit toxicities greater than the uncombined forms. An example is the highly toxic alkyl derivatives of mercury (methylmercury) from elemental mercury by aquatic micro-organisms (WHO, 1992).

Various environmental factors such as temperature, $\mathrm{pH}$, water hardness, dissolved oxygen, light, salinity and organic matter can influence the toxicity of metals in solutions (Bryan, 1976; Dojlildo and Best, 1993; DWAF 1996). Also, the lack of natural elimination processes for metals aggravates the situation. As a result, metals shift from one compartment within the aquatic environment to another including the biota often with detrimental effects, through sufficient bioaccumulation. Food chain transfer also increases toxicological risk in humans. (Rainbow, 1985; Mason,1991). As a result of adsorption and accumulation, the concentration of metals in bottom sediments is expected to be higher than in the water above and this sometimes can cause secondary pollution problems, therefore, bottom sediments are repository of heavy metals. Metals in natural waters can exist in truly dissolved colloidal and suspended forms. The proportion of these forms varies with metals and for different water bodies. Consequently, the toxicity and sedimentation potential of metals change depending on their forms, (Bestemyanov and Krotov, 1985). Non essential metals often exert their action through their chemical similarity to essential elements for example, Cadimium with Copper or Zinc (George, 1982). However, the effects of toxicity are usually additive and / or synergistic (Depledge, 1987).

Essential heavy metals are generally considered to be less toxic than non-essential metals, (Batley, 1993). Metals such as cadmium, chromium, copper, iron, 
nickel, lead and zinc exhibit aquatic toxicity when present above recommended standard in that they can contaminate surface and ground water bodies, soil, plant, aquatic life and man, through bioaccumulation. Bioconcentration of heavy metals over time in aquatic ecosystem has been reported by Alabaster and Lloyd, (1980); Spear, (1981); Friberg et al. (1986); Fischer (1987); Grandwork, (2002). According to Mason (1991), heavy metals pollution is one of the five major types of toxic pollutants commonly present in surface and ground waters. The environmental pollutants tend to accumulate in organisms, and become persistent because of their chemical stability or poor biodegradability and that they are readily soluble and therefore environmentally mobile. Heavy metals form one of the major contributors to the pollution of natural aquatic ecosystems. (Puvers, 1985; Sanders, 1997). The elevated level of heavy metal in the Niger Delta aquatic environment as a result of industrial discharges from refining operations have been elaborated by Atuma and Egborge, (1986); Ikomi and Owabor (1997); Ikomi and Emuh (2000); Spiff and Horsfall, (2004); Brades et al., (2004). The unregulated discharge of untreated influents into natural receptors by industries in Nigeria has also been reported by Egborge, (1994, 2000); Omishakin, (1996).

Warri Refining and Petrochemical Company Limited, Ekpan Warri, generate effluent and discharge it into a natural receptor - River Ijana. Therefore it is important to monitor pollution limits of heavy metals in the aquatic ecosystem carefully, so that approximate measure of the potential hazards can be attained. These measures should give an estimation of the type of effects that could be expected after exposure to heavy metals. Thus, the intent of the research was to obtain information on the concentration and distribution of heavy metals in River Ijana.

Study Area: Warri in Delta State of Nigeria is situated on the north bank of the Warri River, one of three major sinusoidal river which in conjunction with their anastomosing tributary streams and creeks drain the wetlands of the western Niger Delta. The study area (River Ijana) is located within longitude $5.54^{0} \mathrm{E}$ and $5.7^{\circ} \mathrm{W}$ and latitude $5.31^{\circ} \mathrm{N}$ and $5.6^{\circ} \mathrm{S}$ as shown in Fig.1. It stretches from low population density of Ubeji and Ughuotor that generate rural/urban waste that are discharged into the river untreated, it meanders through its course and empties into the Tobi Creek. The activities along the river course include auto-mechanic workshops, petroleum refinery and services, bathing, fishing and swimming. The river is unidirectional in the upper reach and tidal in the lower reach. Its upstream reach is fresh water with dense forest vegetation. The downstream reach is however brackish and consist of Mangrove. The area experienced tropical humidity of the semi-hot equatorial type-with a mean annual rainfall of about $3000 \mathrm{~mm}$ (Alakpodia, 2001). The wet season period stretches from April to October each year, and however with occasional precipitation in the dry season month of November-March.

Table 1: Heavy Metal Concentration in $\mathrm{mg} / \mathrm{l}$ in River Ijana (mean values are replicate of two determination)

\begin{tabular}{ccccccccc}
\hline $\mathrm{SS}$ & & $\mathrm{Cd}$ & $\mathrm{Cr}$ & $\mathrm{Cu}$ & $\mathrm{Fe}$ & $\mathrm{Pb}$ & $\mathrm{Ni}$ & $\mathrm{Zn}$ \\
\hline $\mathrm{SS}_{1}$ & - & 0.060 & 0.037 & 0.020 & 0.046 & 0.025 & 0.030 & 0.122 \\
& $x_{ \pm \mathrm{S}}$ & \pm 0.014 & \pm 0.006 & \pm 0.004 & \pm 0.007 & \pm 0.006 & \pm 0.004 & \pm 0.007 \\
& $\mathrm{CV} \%$ & 23.3 & 15.2 & 21.0 & 15.4 & 22.4 & 14.0 & 5.97 \\
& & & & & & & & \\
$\mathrm{SS}_{2}$ & - & 0.010 & 0.030 & 0.031 & 0.229 & 0.038 & 0.034 & 0.088 \\
& $x_{ \pm} \mathrm{S}$ & \pm 0.004 & \pm 0.010 & \pm 0.014 & \pm 0.008 & \pm 0.010 & \pm 0.010 & \pm 0.012 \\
& $\mathrm{CV} \%$ & 42.0 & 33.3 & 45.2 & 3.6 & 25.7 & 28.8 & 14.46 \\
$\mathrm{SS}_{3}$ & - & 0.100 & 0.067 & 0.050 & 0.109 & 0.058 & 0.080 & 0.100 \\
& $x_{ \pm} \mathrm{S}$ & \pm 0.014 & \pm 0.020 & \pm 0.029 & \pm 0.010 & \pm 0.008 & \pm 0.010 & \pm 0.028 \\
& $\mathrm{CV} \%$ & 14.0 & 29.9 & 58.0 & 8.9 & 14.5 & 12.5 & 28.28 \\
& $*$ WHO & 0.003 & 0.01 & 0.029 & 0.03 & 0.01 & 0.02 & $<1$ \\
& $*$ FEPA & $-<1$ & 0.05 & $<1$ & 20 & $<1$ & $<1$ & $<1$ \\
\hline
\end{tabular}

$* W H O=$ World Health Organization Effluent Standards; *FEPA = Federal Environmental Protection Agency Effluent Standards.

\section{EXPERIMENTAL}

Sampling stations: Three sampling stations were established to cover possible impacted and unimpacted area along the river course based on an earlier field reconnaissance tour. The locations of the various sampling points are;

i) $\mathrm{SS}_{1}$ : About 100metres upstream of the Ijana River from the point of discharge of Warri Refinery effluents. 
ii) $\mathrm{SS}_{2}$ : This is the point of discharge of Warri Refinery effluent.

iii) $\mathrm{SS}_{3}$ : About 100 metres downstream of the Ijana River from the point of discharge of Warri Refinery effluent.

Sample collection and analysis: The composite water sampling method was used in collection of sample in each sampling station twice covering a period of March/August 2003. A 2litre wide mouth polyethylene container thoroughly cleaned was used. Samples were preserved by adding 5 drops of Nitric acid to the samples and stored below $4^{0} \mathrm{C}$ in a refrigerator before analysis. Analyses of parameters were based on the principles and procedures outlined in standard methods for the examination of heavy metals in water and wastewater samples (APHA, 1995). The concentrations of heavy metals in the preserved samples were analysed using a PyeUnicam Atomic Absorption Spectrometry 2900model. All reagents used were of AnalaR grade and all glassware and polyethylene were properly cleaned with acid - cleansing reagents and rinsed thoroughly with distilled deminerized water.

\section{RESULTS}

The level of individual parameters of pollution analysed are presented in Table 1 and in Figure 1a d. Cadmium values ranged between $(0.010 \pm$ $\left.0.004 \mathrm{mg}^{-1}\right)$ and $\left(0.100 \pm 0.014 \mathrm{mgl}^{-1}\right)$ along the river course within the period of study. Seasonality difference existed with higher values of $0.110 \mathrm{mg}^{-1}$ at $\mathrm{SS}_{3}$ during the dry season, while the wet season recorded a maximum concentration of $0.090 \mathrm{mgl}^{-1}$ at $\mathrm{SS}_{3}$. In the same vein, Chromium concentration within the study area varied between $(0.037 \pm$ $\left.0.006 \mathrm{mg}^{-1}\right)$ and $\left(0.067 \pm 0.020 \mathrm{mg}^{-1}\right)$. The concentration distribution in the study area show that $\mathrm{Cr}$ experienced maximum level of $0.081 \mathrm{mgl}^{-1}$ at $\mathrm{SS}_{3}$ during the dry season while at $\mathrm{SS}_{1} 0.022 \mathrm{mg}^{-1}$ was recorded during the wet season as shown in Fig 1(b).

\section{Cd (mgl-1)}

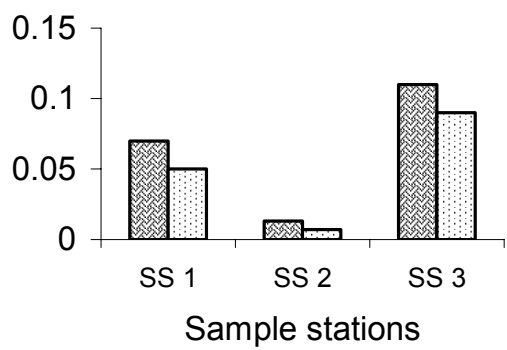

$\operatorname{Cr}(\mathrm{mgl}-1)$

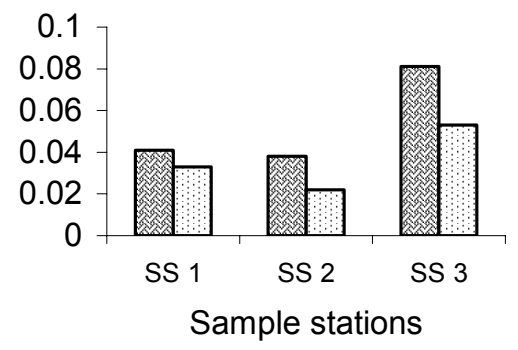

Fig 1a. Variation of $\mathrm{Cd}$ and $\mathrm{Cr}$ in sampling

Copper, Iron and Nickel mean concentrations in the water body ranged between $\left(0.020 \pm 0.004 \mathrm{mg}^{-1}\right)$ and $\left(0.050 \pm 0.029 \mathrm{mg}^{-1}\right) ;\left(0.046 \pm 0.007 \mathrm{mg}^{-1}\right)$ and $\left(0.229 \pm 0.008 \mathrm{mg}^{-1}\right)$ and $\left(0.030 \pm 0.004 \mathrm{mg}^{-1}\right)$ and $\left(0.080 \pm 0.010 \mathrm{mg}^{-1}\right)$ respectively. Also, Copper and Nickel recorded maximum values of $0.071 \mathrm{mg}^{-1}$ and $0.090 \mathrm{mg}^{-1}$ respectively at $\mathrm{SS}_{3}$ during the dry seasons, while Iron recorded maximum value of $0.235 \mathrm{mgl}^{-1}$ at $\mathrm{SS}_{2}$. In the same vein, Copper and Nickel recorded maximum concentration of $0.029 \mathrm{mgl}^{-1}$ and $0.070 \mathrm{mgl}^{-1}$ respectively at $\mathrm{SS}_{3}$ while Iron has maximum concentration of $0.223 \mathrm{mgl}^{-1}$ at $\mathrm{SS}_{2}$ during the wet season.

\section{$\mathrm{Cu}$ (mgl-1)}

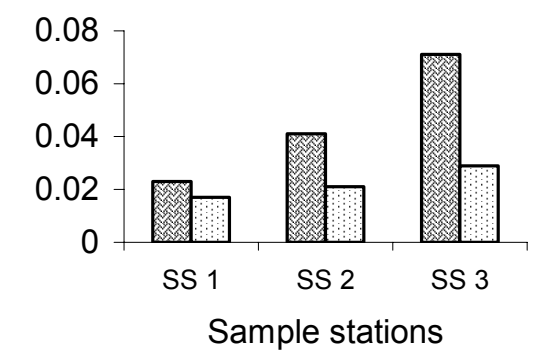

Fe (mgl-1)

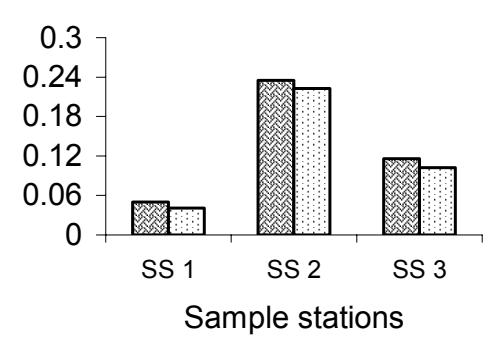

Fig 1b. Variation of $\mathrm{Cu}$ and $\mathrm{Fe}$ in sampling 
Concentration levels of Lead and Zinc in the study area varied between $\left(0.025 \pm 0.006 \mathrm{mg}^{-1}\right)$ and $(0.050$ $\left.\pm 0.00 \mathrm{mg}^{-1}\right) ;\left(0.088 \pm 0.100 \mathrm{mg}^{-1}\right)$ and $(0.122 \pm$ $\left.0.007 \mathrm{mg}^{-1}\right)$ respectively. Higher values of Lead was recorded in the wet seasons, it recorded a maximum concentration of $0.064 \mathrm{mg}^{-1}$ at $\mathrm{SS}_{3}$, while higher value of $0.052 \mathrm{mg}^{-1}$ was recorded during the dry season at $\mathrm{SS}_{3}$. Conversely, Zinc experienced higher concentration of $0.127 \mathrm{mg}^{-1}$ at $\mathrm{SS}_{2}$ during the dry season, Over $0.117 \mathrm{mg}^{-1}$ recorded during the wet season.
Ni (mgl-1)

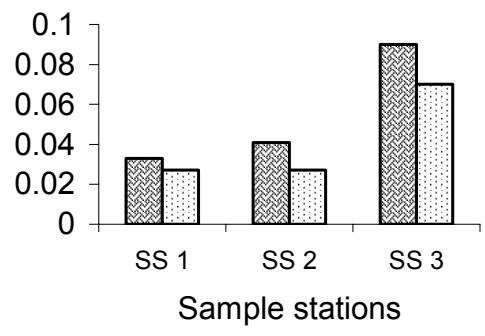

$\mathrm{Pb}$ (mgl-1)

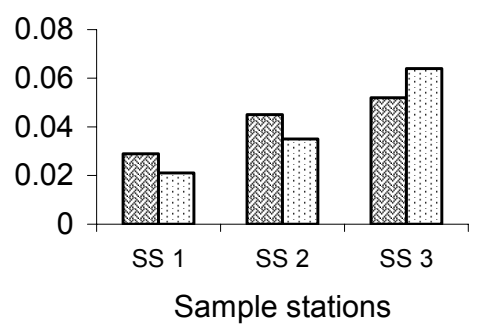

Fig 1c. Variation of $\mathrm{Ni}$ and $\mathrm{Pb}$ in sampling

\section{DISCUSSION}

As shown in figure 1a Cadmium mean concentration level of $0.060 \mathrm{mg}^{-1}$ at $\mathrm{SS}_{1}$ could be attributed to rural / urban effluents along the river course and atmospheric precipitation which support the finding of Robinson, (1996). However, higher value at $\mathrm{SS}_{3}$ is a pointer to the fact that leachate from the refinery sludge lagoon containing Nickel - Cadmium batteries and Cadmium plate items along the jetty and the refinery effluent at $\mathrm{SS}_{2}$ empties into the natural receptor. Cadmium presence in the study area was as a result of industrial discharges, resulting from refinery operations, household wastes such as paints, which supports the earlier findings of Stoeppler, (1991). DWAF (1996); Merian, (1991),

\section{Zn (mgl-1)}

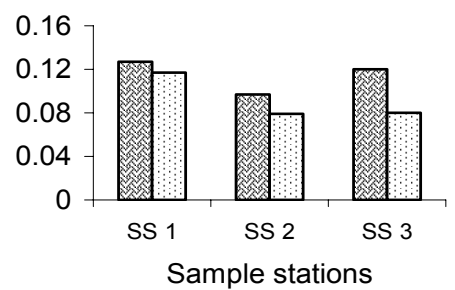

Fig 1d. Variation of $\mathrm{Ni}$ and $\mathrm{Pb}$ in sampling

In view of the fact that the major use of water in the study area is fishing and domestic, the concentration levels of Cadmium recorded exceeded that recommended by W.H.O. for aquatic ecosystem, therefore it is of great concern since Cadmium is extremely toxic and the consumption of water high in Cadmium could cause adverse health effect to end users Since, Cadmium has been found to be toxic to fish and other aquatic organisms, which conforms with similar reports of Woodworth and Pascoa, (1982), Friberg et al., (1986), Kjellstroem, (1986) and DWAF, (1998) The high concentration of Chromium and Copper in the study area could be attributed to the dumping of wood treated with chemicals made from salts of Arsenic, Chromium, and Copper in mixed soluble formulation (as copper-chrome- arsenate preservative) being used the to prevent fungi and pest attack which provide a potential source of chemical spills and drainage from the treated wood within and around the refinery, which support the earlier findings of Ndiokwere, (2004). Similarly, effluent from photographic colour laboratory around the study area could also be a source of Chromium in the River as noted by Brades et al, (2004). The high level of Fe recorded at $\mathrm{SS}_{2}$ and $\mathrm{SS}_{3}$ within the study area could be related to run-of from rusted metallic pipes at the refinery scrap metal dump sites and the refinery sludge lagoon. Also, the presence of Iron in the study area could be attributed to high organic matter and low dissolved oxygen content, in that Iron can easily be absorbed on particulate organic matter or complexed with colloidal organic matter in aquatic 
environment as pointed out by Bryan (1976), Sanders (1997). High concentration of Iron in the Niger Delta has also been reported by (Atiakiru, 1997; Akporido, 2000).

Lead and Nickel high concentration within the study area is a pointer to the fact that naturally, Lead and Nickel are distributed in surface waters due to weathering of minerals and atmospheric deposition (Merian, 1991; Robinson, 1996). Also, Lead and Nickel presence at high concentration in study area could be related to industrial and other technical uses most of which are: electric storage batteries, petroleum refining catalyst, chemical pigment and alloy production, leachate from refining sludge lagoon containing Nickel - Cadmium batteries and Nickel plate items, emissions from burning of fossil fuels and gasoline which contain high levels of tetraethyl lead (TEL) which support the earlier findings of Stoeppler, (1991) and Horsfall, (2001). Zinc level in the study area could be attributed to the high concentrations of Cadmium and Iron in that Zinc occurs in nature with other metals of which Iron and Cadmium are the most common which supports the work of Dallars and Day, (1993).

Conclusion: The levels of heavy metals, namely cadmium, chromium, copper, iron, nickel, lead and zinc were analysed in the River Ijana. Generally, excessive levels of the parameters of pollution above W.H.O. standards recommended for surface waters were observed. This is an indication of pollution. From the distribution pattern of the individual parameters, the downstream point is more contaminated than the upstream point. This is a pointer to the fact that there is unregulated discharge of contaminated effluent into the natural receptor River Ijana without prior treatment by industries and communities within the study area.

Acknowledgement: The authors expressed their profound and indebt gratitude to Prof. R.B. Ikomi, Prof. S.H.O. Egboh and Dr. M. Horsfall Jr. for their scholarly contributions and discussions during the course of this research.

Recommendation: A comprehensive study of physicochemical parameters should be carried out on sediments of Rive Ijana.

\section{REFERENCES}

A.P.H.A. (1995). Standard methods for the examination of water and wastewater $19^{\text {th }} \mathrm{Ed}$. American Public Health Association.
Akporido, S.O. (2000). Analysis of quality characteristics of surface and ground water. Nigeria Journal of Sciences and Environ. 2000 Vol. 2: 17-22.

Alabaster J.S. and Lloyd R. (1980), Water Quality criteria for fish ( $2^{\text {nd }} \mathrm{edn}$.) London: Butterworths.

Alakpodia, I.J. (2001) "Soil Characteristics under gas Flares in the Niger Delta" In: An International Journal of Environmental Policy Issues Olurunfemi J. F. (Ed). Vol. No. 1 and 2. Pp. 2-3.

Albergoni, V. and Piccinni, E. (1983). Biological response to trace metals and their biochemical effects. In: Trace element speciation in surface waters, (Ed.) G.G. Leppard, Plenum Press. New York. pp. 159-175.

Ataikiru, H. (1997). Determination of Heavy metals in soils of Ovwian Aladja. Bulletin of the Science Association of Nigeria. Vol. 21. 35-37.

Atuma, S.O. and Egborge A.B.M. (1986). Insecticide and metals in surface water-Warri River. International Journal of Environmental Studies. Vol. 27; pp. 131-142.

Batley, G.E. (1983). The current status of trace element speciation in natural waters. In: Trace element speciation in surface waters, (Ed.) G.G. Leppard. Plenum Press. New York. Pp. 17-36.

Bestemynov, G. P. and Krotov, J. G. (1985) Maximum Allowable concentrations of Chemicals in the Environment. Khimiya, Lenmgrad Press, Russia.

Braide, S.A., Izonfuo W.A.L., Adiukwu, P.U., Chindah A.C. and Obunwo, C.C. (2004). Water quality of miniweja stream, A swamp forest stream receiving non-point source waste discharges in Eastern Niger Delta, Nigeria. Scientia Africana. Vol. 3. 1-8.

Bryan, G.W (1976): Some aspects of heavy metal tolerance in aquatic organisms. In A.P.M Lockwood (Ed): Effects of pollutants on aquatic organisms Cambridge University Press, Cambridge. Pp 7-34.

Dallas, H.F. and Day, J.A. (1993). The effect of water quality variables on riverine ecosystems: A review, Water research commission Project. No. 351. Pretoria. South Africa. 200pp. 
Depledge, M.H. (1987). Enhanced copper toxicity resulting from environmental stress factor synergies. Comp. Biochem. Physiol. Vol. 87: 119-125.

Dojlildo, J.R. and Best G.A.L (1993). Chemistry of water and water pollution. ELLIS Horwood Ltd., Great Britain.

DWAF (1996). South Africa water quality guidelines, Vol. 7: Aquatic ecosystem $1^{\text {st }}$ edn., Department of Water Affairs and Forestry.

DWAF (1998). Quality of Domestic Water Supplied. Assessment Guide (2 ${ }^{\text {nd }}$ edn.) Vol. 1. Department of Water Affairs and Forest. Department of Health, and Water Research Commission.

Egborge A.B.M. (1994). Water pollution in Nigeria (I) Biodiversity and Chemistry of Warri River. Ben Miller Publisher, Warri.

Egborge, A.B.M. (2000) Government, Oil Companies, The peoples and the Niger-Delta Environment: 4th convocation lecture of Delta State University, Abraka. Nigeria.

Federal Environmental Protection Agency (F.E.P.A.) (1991). Guidelines and standards for environmental pollution control in Nigeria.

Fischer A.B. (1987). Mutagenic Effects of Cadmium atom and in combination with antimutangenic Scienite. Proc. $6^{\text {th }}$ Int. Conf. on Heavy metals in the Environment. New Orleans, Vol.2, CEP Consultants Ltd., Edinburgh. Pp.112-114.

Friberg, L. Elinder C.G, Kjellstroem T. and Nordberg G.F. (Eds). (1986). Cadmium and Health. A toxicological and Epidemiological Appraisal Vol. II. Effects and Response. CRC Press. Boca Raton. Florida.

George, S.G (1982) Subcellular accumulation and detoxification of metals in aquatic animals. In Physiological mechanisms of marine pollutant toxicity. W.B. Vernberg, A. Calabredi, F.P. Thurberg and F.J. Vernberg (Eds): Academic Press New York. Pp. 3-52.

Groundwork, (2002). http://www.groundwork.org.za/chemical profiles.htm.
Horsfall, M. Jr. (2001). Advanced Environmental Chemistry $1^{\text {st }}$ Ed. La Limesters Printer Port Harcourt, Nig. 130-159.

Ikomi, R.B. and Emuh (2000). The status of the physicochemical hydrology of upper Warri river Nigeria. Journal of Science and Environment. Vol. 2. 75-86.

Ikomi, R.B. and Owabor N. (1997). The status and seasonality in the physicochemical hydrology of River Orogodo at Agbor, Nigeria. Bulletin of Science Association of Nigeria Vol. 21. 167-175.

KjellstroemT. (1986). Itai-Itai disease In: Cadmium and heath: A Toxicological and Epidemiological Appraisal Friberg L, Elinder C.G., Kjellstroem T. and Nordberg GF (Eds). Vol. II. Effects of Response. CRC Press Boca Raton, Florida 257290.

Mason, C.F. (1991) Biology of freshwater pollution. 2nd Edition; Longman New York. 351 Pp.

Merian E. (1991). Metals and their compounds in the Environment. occurrence Analysis and Biological Relevance UCH, Weintrein - New York.

Ndiokwere, C.L. (2004). Chemistry and Environment, Inaugural Lecture Series 73, University of Benin, UNIBEN Press, Pp. 33-37.

Omishakin, A. (1986). Environmental pollution and Home Health. Symposium on plant sanitation and Industrial waste disposal, University of Ibadan, Ibadan. $9^{\text {th }}-13^{\text {th }}$ Sept., 1986 .

Purves, D. (1985). Trace element contamination of the environment. Amsterdan; Elsevier.

Rainbow P.S. and Dallinger, R (1993) Metal Uptake, regulation and excretion in freshwater invertebrates. In R. Dallinger and P.S. Rainbow (Eds). Ecotoxicology of metals in invertebrates. Lewis Florida. Pp. 119-131.

Rainbow, P.S and White, S.L. (1989). Comparative Strategies of heavy metal accumulation by crustaceans: Zinc, Copper and Cadmium in a decapodan amphipod and a barnacle. Hydrobiologia Vol. 174: 245-262.

Rainbow, P.S. (1985), the biological of heavy metals in the sea. I Environment studies. Vol.25: 195211. 
Robinson. J. (1996) evaluation of a health assessment index with reference to bioaccumulation of metals in Oreochromis massambicus (peters 1852) and aspects of the morphology of Lernaea Cyprinacea. Linnaeus, 1758. Thesis, Rand Afrikaans University. South Africa.

Sanders, M.J. (1997) A field evaluation of freshwater river crab, Potamonautes warreni, as a bioaccumulative indicator of metal pollution. Thesis, Rand Afrikaans University, South Africa.

Spear P.A. (1981). Zinc in the aquatic environment; Chemistry, Distribution and Toxicology. National Research Council of Canada, Associate Committee on Scientific Criteria for Environmental Quality. Report NRCC No. 17589. Ottawa.
Spiff, A. I. and Horsfall. M. Jnr. (2004). Trace metal concentrations in Inter-Tidal flate sediments of the upper new Calabar River in the Niger Delta area of Nigeria. Scientia African. Vol 3. 19-28.

Stoeppler M. (1991). Cadmium In: Metals and their compounds in the environment: Occurrence, analyses and biological Relevance. Merian E. (Ed.) VCH, New York. 803-851.

WHO (1992). GEMS/WATER Operational Guide. Third edition World Health Organisation, Geneva.

Woodworth J.C.and Pascoe V.(1982).Cadmium toxicity to rainbow trout. Salmon gairdneric Riehardson. A study of eggs and alevins. J. Fish Biol. Vol.21: 47-57. 